\title{
'Floating Public Space' for Birds: Design Research and Prototype Fabrication in Haliç
}

\author{
Kutay Karabağ $1 \odot$, Zeynep Şahbaz $2 \odot$ \\ ${ }^{1}$ Lecturer, Faculty of Architecture, Bilgi University, Istanbul, Turkey. (Principal contact for editorial correspondence), Email: \\ kutaykarabag@gmail.com \\ ${ }^{2}$ Graduate Student, Faculty of Architecture, Bilgi University, Istanbul, Turkey. Email: zeysahbaz@gmail.com
}

\begin{abstract}
Purpose

This text intends to discuss the outcome of the graduate design studio titled 'hydrophilic structures'. Studio research is organized on two primary axis; revealing the potentials of floating spaces as an extension of public spaces on one hand, and digital design and fabrication technologies for prototyping on the other. Concepts such as floating structures, water interaction and public space may initially refer to human utilization however, non-human living organisms are critical for their decisive role on the qualities of the water and the urban environment.
\end{abstract}

Design/Methodology/Approach

Design of floating structures and water interaction had been a niche inside the traditional culture and practice of architectural design, whereas design and production skills in connection with water had historically developed mostly in the field of engineering and transportation. Floating structures and their potential for unconventional spatial experiences have recently engaged in the focus of contemporary design culture, mainly due to the increasing density and lack of public spaces on the land.

\section{Findings}

The proposal, designed through computational tools and fabricated through robotic technology, concentrates on various ways of interaction with water and acknowledge research on the spatial requirements for the birds, as the users of space.

\section{Research Limitations/Implications}

Fabrication of the floating prototype is assumed as a primary target for its observation potential enabling an original discussion of the design parameters for bird species. Limitations of the existing fabrication tools and sustainability of the practically available materials were assumed to be out of the scope of this study.

\section{Social/Practical Implications}

Design-research presented here covers principal case-studies of floating spaces, the buoyancy principles, material tests and essential variables of ecological dynamics in Haliç as a general framework.

\section{Originality/Value}

The subsequent prototype serves for a specific bird population utilizing Haliç as a part of their life cycle, rather than human utilization.

Keywords: Floating structures, hydrophilic design, robotic fabrication, floating space, Haliç 


\section{INTRODUCTION}

All the early settlements established around Bosphorus and Haliç (Golden Horn) depend on the benefits of the water connection in terms of trade, defence and fertility (Yllmaz, 2008, p.120). Utilization of the shores of Haliç had varied beginning from the Byzantian settlement around Sarayburnu and progressed through the inner areas. In the Byzantine period, whole Haliç turned out to be a big trade harbour and commercial and residential areas formed on its shores. Historically, it is possible to observe spatial and cultural typologies, both public and private, of human utilization and interaction with water, particularly on these shores.

On the other hand, public utilization of the shores of Haliç had been impaired by particularly the industrialization of the area in the 20th century and furthermore neo-liberal urban and economic policies after 1980. While public spaces on the waterfront diminish, the urban employment of water is reduced to transportation purposes in a limited scale, which neither contributes for spatial diversification of the waterfront nor enriches the historical experience of interaction with water.

This study intends to present the outcome of the graduate design studio, titled 'hydrophilic structures', as an experimental design research on floating structures and their contribution to public utilization of the shores. Studio research aims to discuss the problems and potential of public utilization of Haliç and design a sustainable floating open space proposal which will contribute to Santralİstanbul campus in a positive, sustainable and sensitive way. This text initially presents the research and discussion on the context, focusing on the historical and contemporary public utilization of Haliç in order to contribute to the design criteria. This is followed by research on the case-studies of floating structures. One of the proposals is presented in detail at the fourth part with references to the design criteria, process and fabrication. The text is finalized with a conclusion for critiques as well as a brief discussion on possible future research.

\section{BACKGROUND OF CONTEXTUAL WORK Spatial History of Haliç}

Haliç, similar to the Bosphorus, is assumed to be a valley filled with water following the last ice age, and lies almost perpendicular to the Bosphorus in the northwest direction up to the point where Alibeyköy and Kağıthane Rivers meet (Yllmaz, 2008, p. 5). Thanks to its geographic formation, it provides a safe waterway of approximately $7 \mathrm{~km}$ in length, connected to clean waters on both sides. Besides, waters and surrounding land delivers rich fishing and agricultural potential. The early Byzantion settlement had been located around Sarayburnu area, right on the southern corner where Haliç meets with Bosphorus. As the urban form of the city expanded, Haliç had always been one of expansion axis for fishing, 
trade and waterway activities were the primary income for the city (Yilmaz, 2008, p. 10).

Particularly after 324 A.D., when the city is conquered by Romans and converted to be Constantinopolis, the city comes forward as a trade centre. The inner harbours, located on both sides of the entrance of Haliç operate the significant part of this trade, resulting in further developments on the land behind. As the waterway was enchained in the 8th century, the safety is increased, and during the 13th century the whole waterway was utilized as a large harbour composed of docks, each specialized for various goods.

The importance of Haliç and its trade potential increased further following the Ottoman conquest in mids of 15th century, leading to more docks on the southern shore and the imperial shipyard on the northern. Additional residential areas were developed on the inner parts of the waterway, such as Fener, Balat, Eyüp and Kasımpaşa, inhabited by Greek, Armenian and Jewish populations as well as Muslims. Triggered by increasing residential and commercial density, early forms of fabrication ateliers emerged around Haliç shores and Alibeyköy and Kağıthane Rivers, particularly in the 16th century.

Figure 1. Kağıthane (Photograph by Abdullah Fréres)

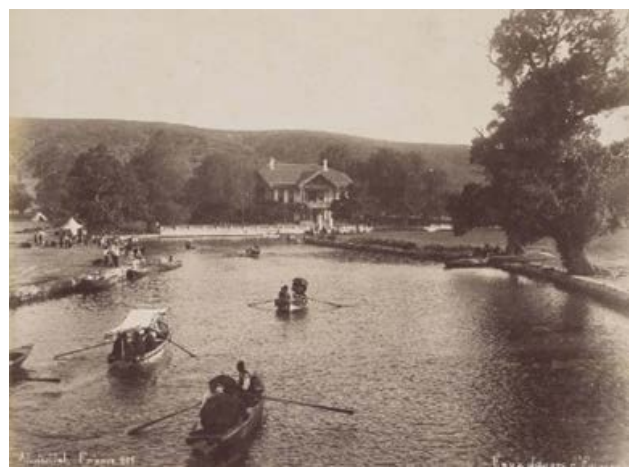

In the 18th century, depending on the new lifestyle of 'Tulip Period' and westernization dynamics in Ottoman Empire, interest into leisure activities increased drastically, resulting in the new construction of summer palaces, mansions, gardens and kiosk on the shores of Haliç and Kağıthane River (Yılmaz, 2008, p. 111). Such leisure activities were usually engaged with boat trips on the calm waters. In the 18th and 19th century, Haliç shores demonstrate an elegant and high-quality silhouette in terms of architecture and landscape. It is possible to assume a rich and colourful life on the waterway, generated by various sailing vehicles for transport and leisure purposes, as well as fishing activities.

Beginning with the second half of the 19th century, İstanbul became the centre of imperial industry, hosting new facilities, funded by foreign capital particularly after the Free Trade Agreement in 1838 (Köksal \& Ahunbay, 2006, p. 126). For the industrialization of the Ottoman Empire, Haliç had been one of the preferred areas for a variety of advantages such as water connection, cultivable land, protection and proximity to central 
urban areas. At the beginning of the 20th century, Haliç accommodates shipbuilding facilities on the northern shore, brick building on the inner parts, food and textile production facilities on the southern shore, tobacco and soap industry on the slopes (Köksal \& Ahunbay, 2006, p. 131). In order to fulfil the increasing energy demand generated by the industrialization, the strategic location at the inner end of Haliç where Alibeyköy and Kağıthane Rivers meet, was selected for the first coalbased urban-scale power plant of the Empire. The location offers confident coal transportation on the south and continuous delivery of essential clean water through two creeks on the north (Aksoy \& Açlkbaş \& Akman, 2009). Moreover, Silahtarağa benefits for proximity with the industrial facilities around Haliç as well as primary urban areas of Pera and Historical Peninsula. Activation of Silahtarağa Power Plant in 1914 marks a significant point on the course of industrialization and westernization of the Ottoman society, bringing late but widespread distribution of the most recent form of energy to the Capital and triggering transformations on the social and economic life of people as well as urban form (Aksoy \& Açıkbaş \& Akman, 2009).

Some areas around Haliç were zoned for industrial functions in the early planning studies by Henri Prost in the Republican period, and modern industrial facilities, as well as small ateliers, were populated around the shores beginning in the 1940s. However, effects of continuous industrialization lead to results such as general pollution, migration and severe decrease of the water depth in Haliç. Revitalization and cleaning projects were practised beginning form end of the 1970s and more actively in the 1980s. It is possible to observe an urban, spatial and social transformation in the districts of Haliç beginning with the 1990s and particularly in 2000s. Public and private cultural and educational institutions usually refurbishing the industrial heritage are essential components of such transformation. As an example, Bilgi University was assigned for both conserving and transforming Silahtarağa Power Plant campus into a hub of education, culture and art spreading the creative energy of the 21st century throughout the city, and opened in 2007 as a public space including museum and exhibition spaces, university functions, offices, food and beverage services.

\section{Case-studies on Floating Space}

As indicated above, although Haliç shores had always been strategic and significant throughout the historical development of İstanbul, the diversity and quality of life reached its utmost level in the 18th and 19th centuries. As a safe trade harbour full of docks and market buildings, as a waterway utilized for transportation and as a leisure area spatialized by landscape areas and mansions, the urban image around Haliç shores usually involved of water-related structures such as a large variety of vessels and coastal arrangements.

A unique example of water structures in the urban image of İstanbul is sea bath, a wooden structure generating open and closed spaces above 
the water surface. Sea baths were designed to fulfil the cleaning and swimming requirements of the citizens proper with religious and ethical criteria. Depending on the record of Evliya Çelebi, it is deduced that sea baths were a component of social life before the 17th century. However, effects of westernization probably increased the popularity of sea baths particularly in non-muslim neighbourhoods, and it is known that there are two sea baths on the waters of Haliç in 1847 (Çelik, 1998).

Traditionally sea baths were built on a platform standing on wooden pillars fixed on the seabed. The platform is usually rectangular in shape, encircling a body of water in the middle like a pool and connected to the coast employing a wooden dock (Koçu, 1966). In some cases, the structure is more articulated with extensions such as diving towers. Closed spaces on the wooden platform served as changing rooms, toilet and coffee-house and mostly covered with a canvas as the ceiling (Evren, 2000). Sea baths were mostly temporary structures where the whole structure or parts of it were dismantled before winter and rebuilt before summer.

Besides sea baths as a traditional example, contemporary water structures and floating spaces are examined throughout the research process, and five substantial cases are presented briefly below.

Figure 2. Courtesy of the Recyled Islands (Photograph by the Business Insider)
Figure 3. Floating Island (Photograph by the Rivista Italiana di Ornitologia Research in Ornithology, 88)

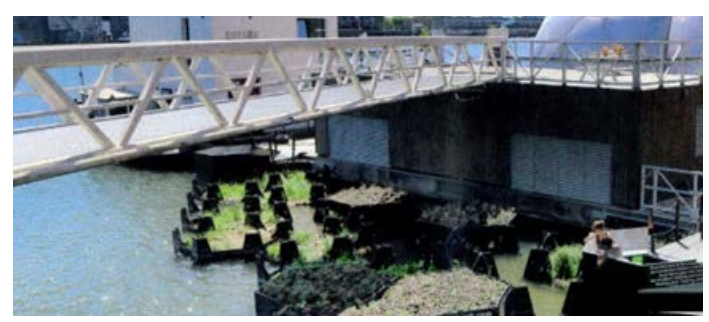

Recycled Park is a floating landscape built from material recycled from the waste in water in Rotterdam. The proposal is composed of debris traps on the water to collect raw material and floating hexagonal plastic units as recycled forms of the debris. For this prototype, units function mostly as green areas and the project can be read as a $140 \mathrm{~m} 2$ floating extension, not only contributing the environment positively as a park, but also directly enriching the fauna for particular living organisms. Moreover, it is possible to vary the functions and increase human utilization, thanks to its modular and flexible design (Berke, 2018).

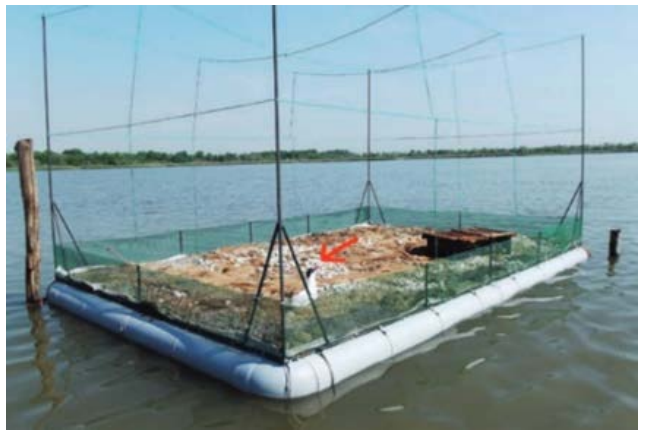


Floating Island for Tern Habitat is a simple artificial floating island aiming to create more space for terns in addition to other conservation actions for announced natural conservation areas in Poland. Representing many similar examples, the project consists of a lightweight modular concrete floating base, covered with biodegradable material suitable for plantation purposes. The floating island is designed similarly with the most common sea bath typology in İstanbul, namely encircling a rectangular pool in the centre. Through this design terns, gulls, and some other bird species are expected to find more space for breeding and feeding in addition to the decreasing natural sand and gravel pits in the area (Coccon \& Borella \& Simeoni \& Malavasi, 2018).

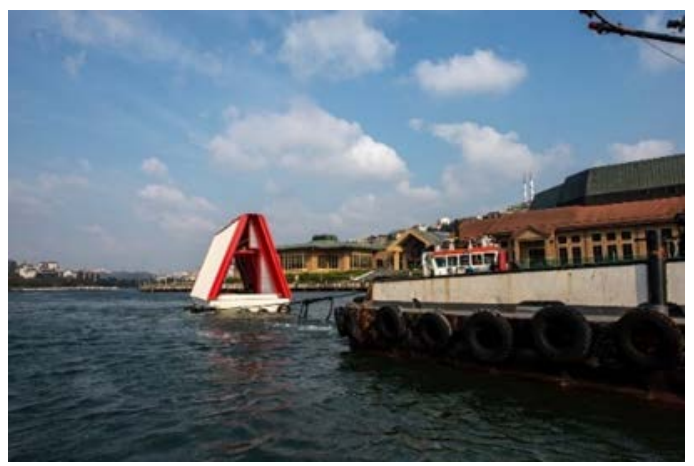

Designed and prototyped for the 4th Istanbul Biennial by SO? Architecture and Ideas in collaboration with MEF University and Boğaziçi University, project title 'Hope on the Water', proposes a temporary floating shelter for possible urban disasters such as an earthquake. Based on solid reasoning such as the modularity and mobility advantages of floating spaces for post-disaster scenarios, the project proposes a light and foldable unit, fully equipped to serve victims as temporary accommodation. The design is composed of a light concrete pontoon as a floating platform and a foldable light steel construction forming the accommodation space. The prototype was built to float on the waters of Haliç for its tsunami-safe geography (Ravenscroft, 2019).

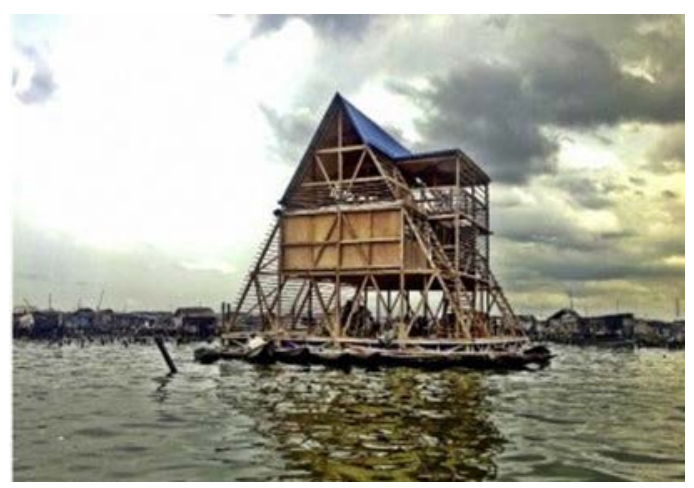

Makoko Floating School is a well-known floating structure, designed to serve for the low-income settlements in Makoko, Laos, by NLE Architects. The design is inspired by the vernacular typology of water housing
Figure 4. Hope on the Water (dezeen magazine 3 January 2019- Photography by Kayhan Kaygusuz)

Figure 5. Mokoko Floating School (In Current Opinion in Environmental Sustainability - April 2015 Photograph by Riise, Jan; Adeyemi, Kunlé) 
structures while converting it to a floating structure. The floating base of the structure is composed of plastic barrels, some of which are also utilized for storing rainwater. Over this platform, lies a sizeable triangular structure, mostly built up with wooden material. Floating potential enables the educational space to announce a broader range of communities. This way, it may contribute to the resilience of some of the most vulnerable areas (Riise \& Adeyemi, 2015).

\section{METHODOLOGY}

This study aims to design floating structures in order to contribute to the public spaces around Haliç. For this reason, history, qualities and problems about public spaces around the coastline were analysed. In parallel with the form and material studies based on floating spaces and fabrication potential, the above research outcome triggered various discussions and proposals. Modularity, scalability and temporality had been the leading concepts throughout these discussions. On the other hand, any spatial production without a regenerative contribution to the ecosystem in Haliç would increase the effects signified above. For this reason, designers had decided to develop spatial design ideas that can positively contribute to the conservation or regeneration of the natural life of living organisms in Haliç. In order to simplify the scale and fabrication of the solution, designers proposed a modular ecological island for a specific bird population. The design promises contribution for the current ecological balance, by being a part of the cycles of the ecosystem. This proposal is an attempt to draw attention to the ecosystem on a central location in the urban context of the city, as well as it aims rejuvenation of the existing public recreation areas through the restoration of ecological cycles. Moreover, it will contribute indirectly to the qualities of the human-based public spaces as well as some other species by means of it's contributions for the bird population.

\section{FINDINGS OF THE STUDY}

Design and prototyping of a floating space on the waters of Haliç requires en extensive and multi-disciplinary research and integrated fabrication technologies. Based on the analysis and historical research on the ecology, coastal character, and public utilization of Haliç, the graduate studio had concentrated on simple floating structures which can sustainably contribute to the ecological properties and public qualities of Haliç, while generating the minimum damage. Hence the following parameters are defined as the primary criteria of design.

\section{Analysis of Public Spaces around Haliç}

The existing public spaces on the shores of Haliç are analyzed in terms of their scale, function, continuity and capacity, identifying the following findings 


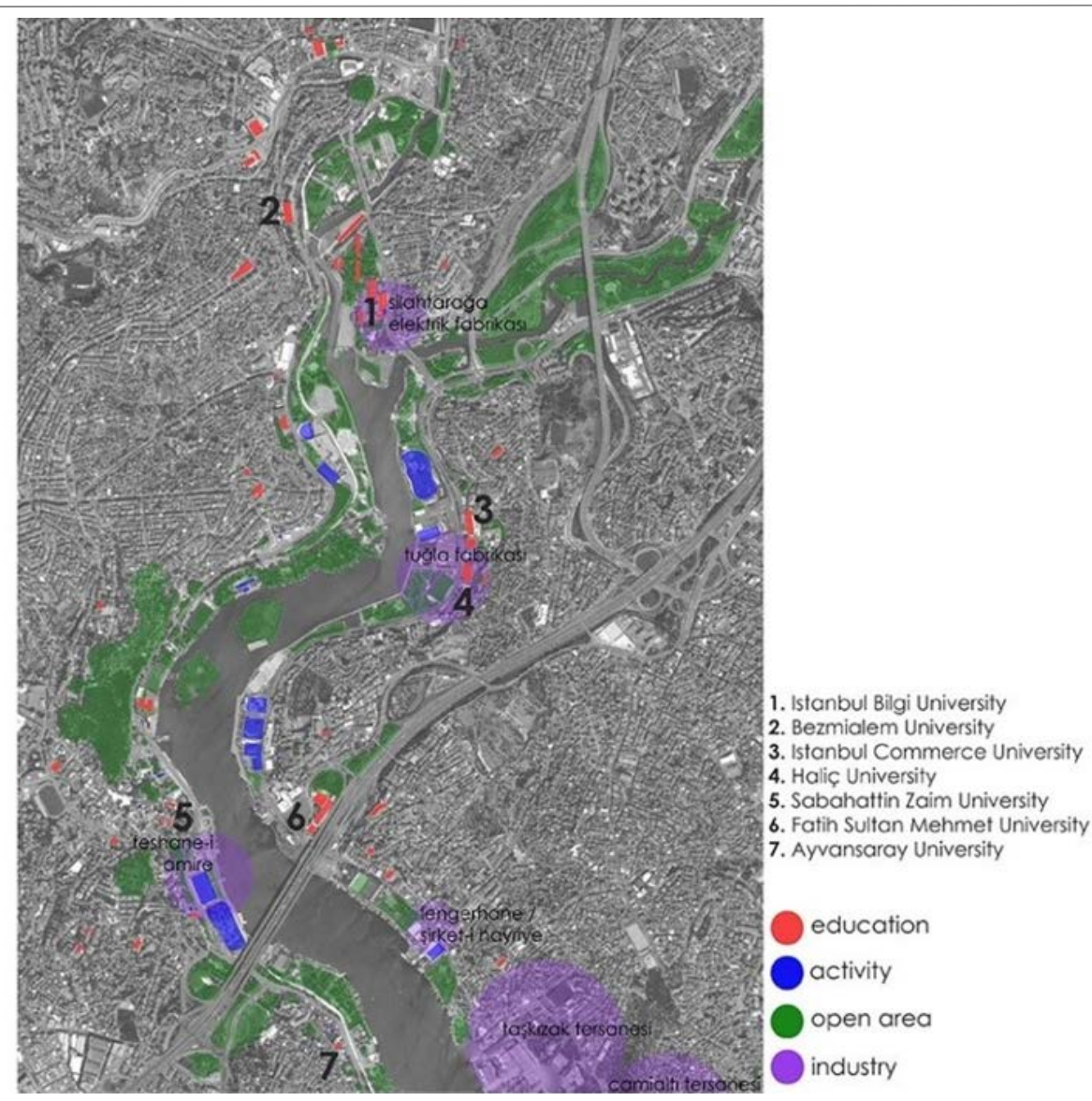

1.Poor utilization of coastal public spaces: There is a variety of public functions around the waterway and the coast is usually reserved for public use, but a few exceptions. However, since holistic planning is lacking, some of these areas are poorly utilized for reasons such as improper functional organizations, unsatisfactory access and inadequate transportation facilities. Moreover, some of these areas are invaded by private functions such as restaurants and retail spaces. Unfortunately, the number of these cases are rapidly increasing.

2.Disconnection of the coast from the urban fabric: A continuous and fast road runs parallel on both sides of Haliç, generating a disconnection with the commercial and residential fabric on the other side, opposing with the traditional use. The public space on the coast is defined by this road as a disconnected and non-continuous narrow band, enormously decreasing the possibility of interaction with water.

3.Disconnection of the two sides of Halic: Although both shores possess similarities in their urban character and functions potentially supporting each other, they are not connected physically for triggering mutual interaction. Existing bridges mostly operate for vehicle traffic and lack for establishing connections between public spaces and functions of the two sides. Galata Bridge laying on the entrance of the waterway is an exception, however not satisfactory. Passenger transportation on the ferry in Haliç started from the second half of the 19th century (Akyldız,
Figure 6. The ones shown in red are 7 listed university campus buildings. The activity areas shown in blue are generally the areas where sports, art and cultural activities are held. Those shown in green are where the greenery is publicly available. Finally, the regions shown in purple colors show the places used as the industrial center in the past. (Research and map composition by Zeynep Şahbaz, Behzad Jam, Shirin Housseinzadah, Mihrimah Yılmaz and Kübra Halıcı). 
2007) and still proposes the quickest and most efficient way of connection between both sides of Haliç.

4.Influence of mass urbanization on the ecosystem: As a natural formation, Haliç waterway is a complete ecosystem including living organisms other than humans. Lacking natural conservation measures, all the living organisms in this ecosystem are at risk in connection with the harmful effects of the urbanization, resulting in the degeneration of the landscape. Bahariye Islands are currently the only area suitable for natural life in the ecosystem.

\section{Water Interaction and Floating}

The design research on floating spaces has been one of the primary parameters shaping the final proposal of this study. Throughout the process, form proposals were developed to be tested for their floating capacity, initially on the computer simulations and followingly as smallscaled models in the fabrication lab. Utilizing these test workshop, a variety of materials such as wood, plastics and filament were also tested as the sub-parameters of the form. Finally, larger prototype models were produced and observed on the water for design problems in terms of interaction with Haliç water, wind and living organisms.

Figure 7. Floating Workshop Test (Photograph by the Authors).

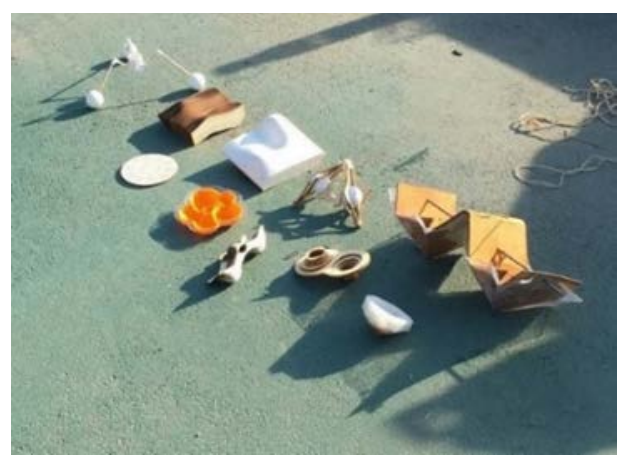

\section{Birds}

As a result of observations and research, the presence of the bird population living along with the Haliç coast and Haliç (Bahariye) islands is of considerable importance. These two small islands mainly provide the only natural and suitable earth habitat for the living conditions of the birds, surrounded by dense urban fabric.

Most bird species have three main stages in their life cycle: breeding, wintering, and migration. The primary purpose of birds when wintering is to feed and survive. During this period, birds can disperse relatively freely, depending on the availability of food and weather conditions. On the other hand, birds are most selective in terms of location preferences in the breeding period as opposed to migration and wintering. Birds select nesting areas according to criteria such as feeding potential and security for themselves and their offsprings, in order to detect, anticipate and avoid future threats, they need to recognize the breeding grounds extensively. Therefore, the presence of a species or a group of species that 
form an ecological association in a specific area during the reproductive period can be used as a clear ecological indicator (Türkiye Üreyen Kuş Atlası, 2019). In light of all this information, the biological preferences of the birds that are utilized as design input.

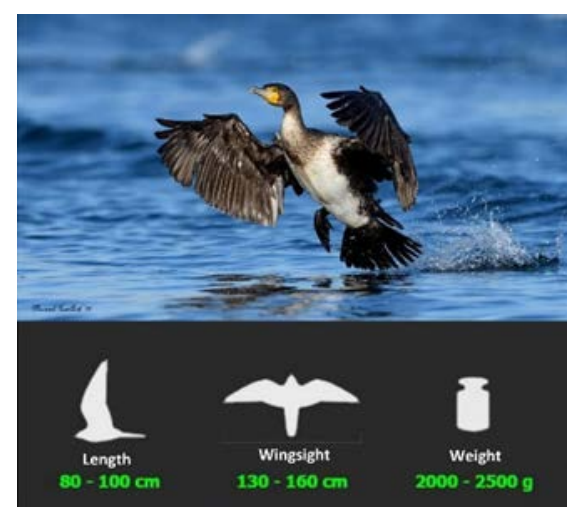

Bird species densely hunting, breeding and resting around Haliç are crested cormorants (tepeli karabatak), cormorants (karabatak), mallard ducks (yeşilbaş ördek), silver gulls (gümüş martı), tern (sumru) and grey

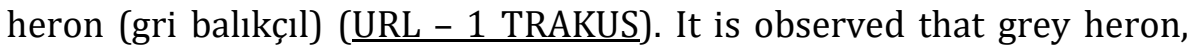
mallard duck, and silver seagulls can live together, particularly around Bahariye Islands. Cormorant is a bird that is seen all year long and that reproduces in small numbers (Boyla, 2008). According to the results of IUCN, the crested cormorant bird is the least breeding and endangered bird among these bird species. Based on these facts, one of the objectives of the project is; to create an adequate breeding-resting area for the species and to contribute to the continuity of the species (KOSKS Report, 2018).

\section{Aquatic Plants That Purify Water}

During the historical development process, the estuary water became increasingly polluted by the positioning of industrial buildings on the coastal edges. In time, this situation had triggered a cleaning project, so that basically water was pumped from the Marmara Sea to Haliç while local water was ventilated by a water jet. While these measures purified the water quite a bit, Kağıthane and Alibeyköy streams were poured and cleared off the odour while increasing the salinity of the water. The estuary water is still dirty to some extent and has a bad smell leastwise. In order to contribute to the ecology of the inhabitat, design criteria for the floating space are targeted to operate in closed cycles, not producing any waste. For this reason, while the droppings of the birds are food for the plants, the plants that contribute to the cleaning of the water of the Haliç will increase the feeding potential of the birds.

Fox Tail Plant which lives mostly in freshwater, is a plant with high tolerance (URL - 2 Sutopya). Although it is an aquarium plant, it is mostly used in aquariums where water balance and $\mathrm{pH}$ levels are atypical. It may clean the water by reducing the bacteria and nitrate levels. Employment
Figure 8. Great Cormorant (Photography by the trakus.org). 
of this plant will enable cormorants to feel safe by providing a natural habitat and contribute to the estuary life by increasing the living quality of the living creatures.

If it is planted, the roots of the plant may die, and it will have a positive effect in terms of maintenance and development. According to the tests carried out in the Kağıthane region in the Istanbul Water Quality Report, the $\mathrm{pH}$ of this region is 6.93. This study was aimed to investigate the potentials of the Foxtail plant in the salty waters of Haliç in the context of cormorants and ecological island (URL - 3 İSKİ Report, 2019).

\section{Materials and Production Technology}

Since the graduate studio was targeting the production of the prototype in a limited time scale, design and fabrication activities should be integrated, providing a continuous test, feedback and optimization cycle. Particular features of this design, such as interaction with water and natural life requires the selection of proper materials and production technology that is significantly determinant for the accomplishment of the design targets. Although the design process had started with formal research on floating abilities, independent from the available fabrication technology and even materials, these constraints were included in the design criteria in the following design phases. The participants were required to develop their design to maturity in parallel with experiments on the material choices and fabrication opportunities available in Istanbul Bilgi University fab-lab, such as laser cutting, CNC, hot wire cutting, vacuum modelling and the robotic arm.

The modular character of the design requires a modular fabrication technology in direct connection with the digital design medium where the form is designed and tested for the floating properties and structural requirements. Secondly, the proposed form requires a certain level of plasticity for both aesthetic as well as functional reasons deduced through research on the lifecycle of cormorants. Namely, interaction with birds entails a variety of design parameters which imposes proper and appealing tectonic quality and surface properties for the birds. Moreover, the outcome prototype is required to perform some flexibility for the dynamic structural forces exerted by water and wind. At the same time, the design necessitates excellent durability against the humidity and minerals of Haliç water together with pecking of the cormorants. Finally, aquatic plants ask for suitable materials on the plantation surfaces of the design.

\section{DESIGN RESEARCH}

It is difficult to separate the process into phases since it had been a multidisciplinary and multi-scale process with continuous feedback, however it will be abstracted here to a more systematic mode in order to clarify the variety of the work and their contribution each. The initial workshops on buoyancy principles provided the participants to experience and test the behavior of various forms and materials. Throughout the individual 
proposals, similar forms were combined and unsuccessful ones were eliminated by the studio instructors.
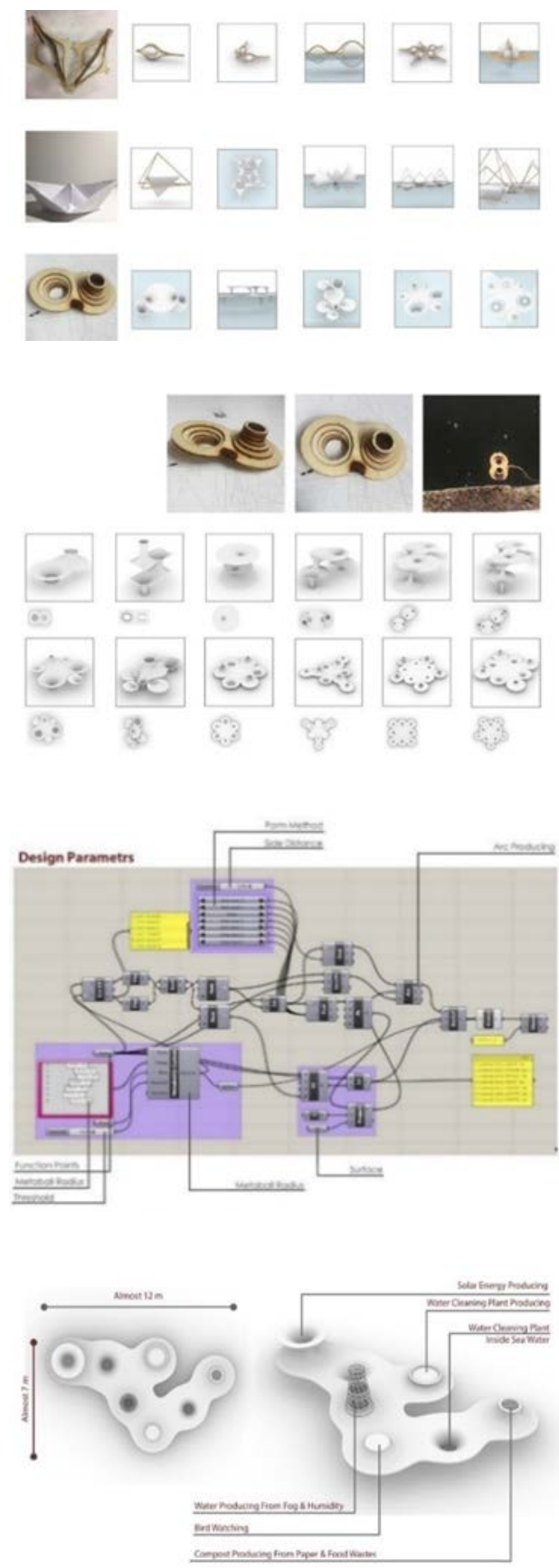

For the following stage, participant groups were asked to model their floating designs for testing, optimizing and elaborating in the digital medium. In this stage, two separate digital tools were utilized for buoyancy and wind performance of the models. For testing the floating performance of the forms, an algorithm on the Grasshopper platform, developed by Oğulcan Üneşi was employed. Although the proposal discussed in this paper is comparatively a flat surface structure which is naturally floatable with the correct material, the duality of the pool and tower parts demonstrated imbalanced configurations on the tests.
Figure 9. Relationship Structure and Water (Photograph by the Designers)

Figure $\quad 10 . \quad$ Form Development (Photograph by the Designers).

Figure 11. Function \& Development (Design by the Designers).

Figure 12. Design Parameters (Design by the Designers). 
Figure 13. Scaled Test I (Photograph by the Designers).

Figure 14. Scaled Test II (Photograph by the Designers).
Design Research and Prototype Fabrication of a 'Floating Public Space' for Birds

Additionally, wind performance of the designs was tested through Archidynamics software, proving no problems.
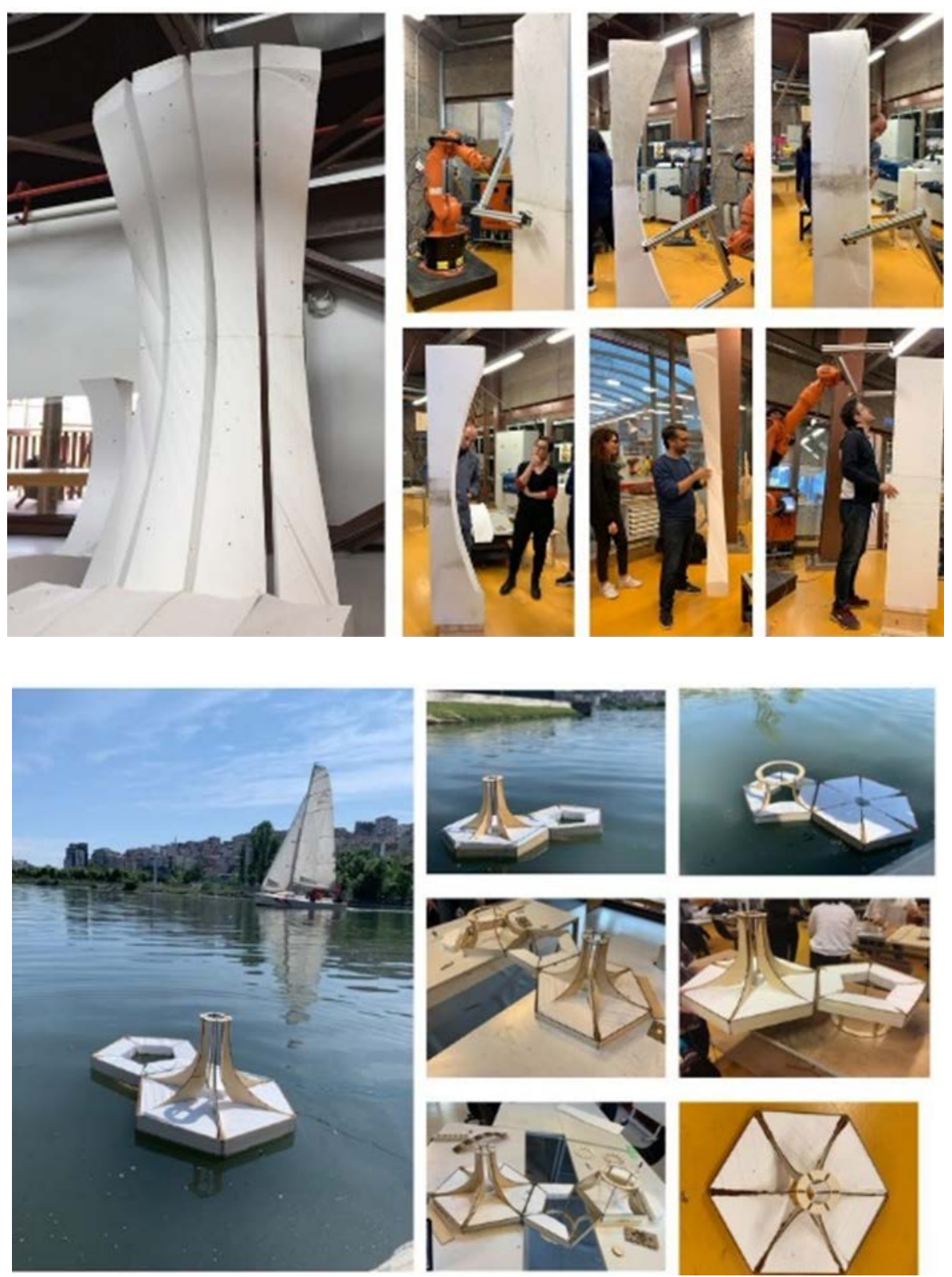

Following this stage, participants were asked to develop their designs in terms of spatial properties, functions and connection with the coast, utilizing the experience they accumulated through the initial workshops. In parallel, they were required to develop the fabrication techniques together with the material choices, which included modularity as a constraining parameter in the design process. The early version of the proposal, examined here, was a $7 \times 12 \mathrm{~m}$. free-form shape serving for more complex functions such as photovoltaic cells and compost production as well as human utilization.

As the fabrication constraints were included in the problem, the designers of the proposal offered a parametric design system for a 
circular base and two modes of extensions, into the water surface and the opposite direction. Through dividing the circular structure into triangular slice units, the whole system turned out to be a modular floating structure which can be parametrically designed for various functions and dimensions to be fabricated employing the same design logic. A group of these modules were optimized digitally for KUKA robotic arm utilizing wire cutter head and fabricated in scale from foam material as a floating prototype.
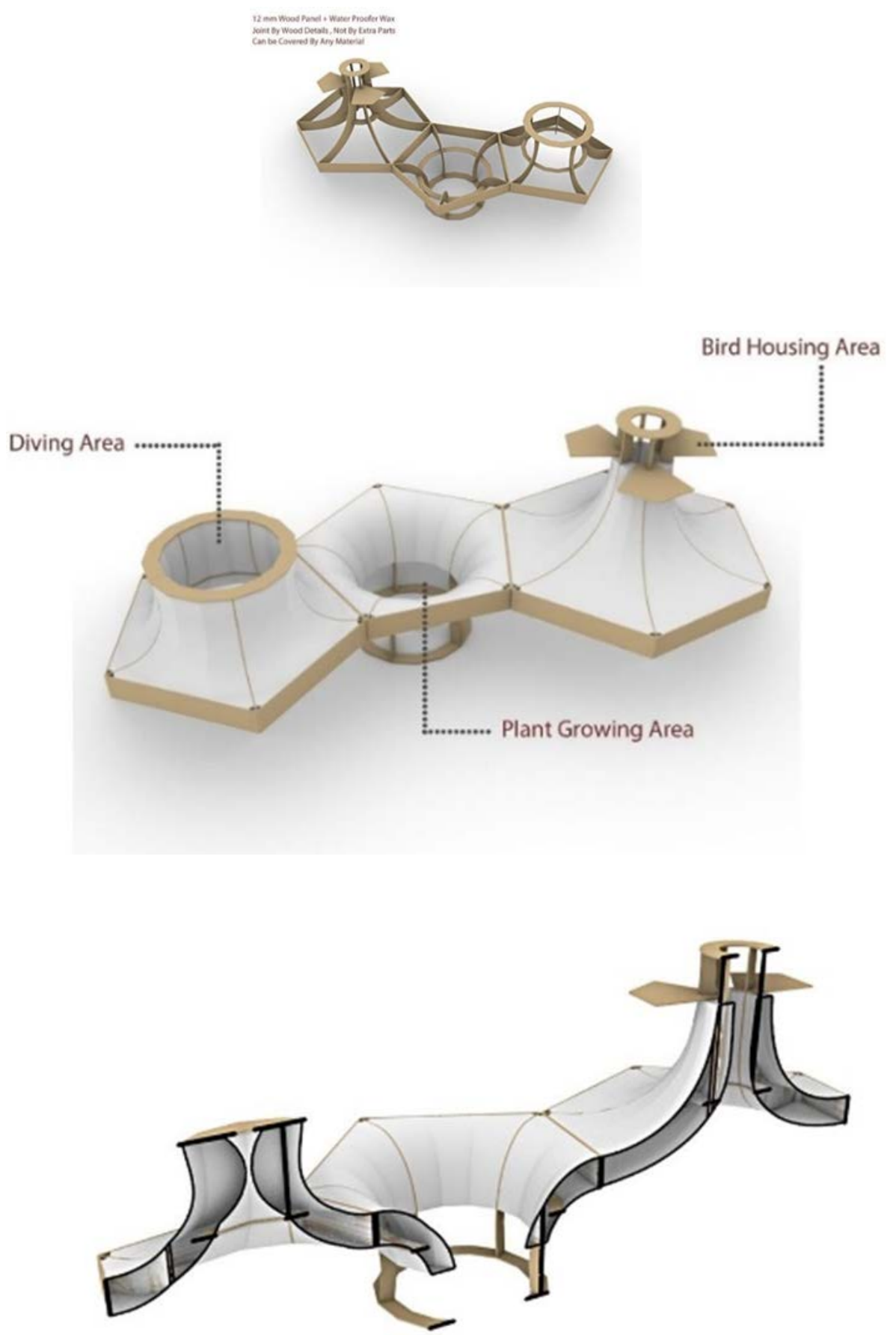

Figure 15. Designed Structure (Design by the Designers).

Figure 16. Structure (Design by the Designers).

Figure 17. Form Dimensions (Design by the Designers). 
Based on the real-life tests on the water and jury critiques, the design proposal was optimized further and simplified for incorporating with the fabrication technology and budget. The most significant simplification had been avoiding the human use and limiting the users of the proposal with birds. Hence the dimensions and structural performance requirements of the prototype were decreased drastically. Secondly, the circle based curvilinear form of units were converted into pentagon and hexagon bases for simplifying fabrication difficulty and time.

The final proposal is composed of 3 parts; diving area and bird platforms established by concave forms of the preliminary design and the plant growing area as the convex version in the middle. The reservoir (plant growing area) of the hydrophilic structure was designed to grow edible plants by species in Haliç and to perch / breed cormorant birds at risk.

Figure 18. Section Views (Design by the Designers).

Figure 19. Section (Design by the Designers).

Figure 20. Paste, Isonem MS Polymer, Isonem Super Component

Coating materials have been tested on foams. Photos taken in material testing (Photograph by the Authors).

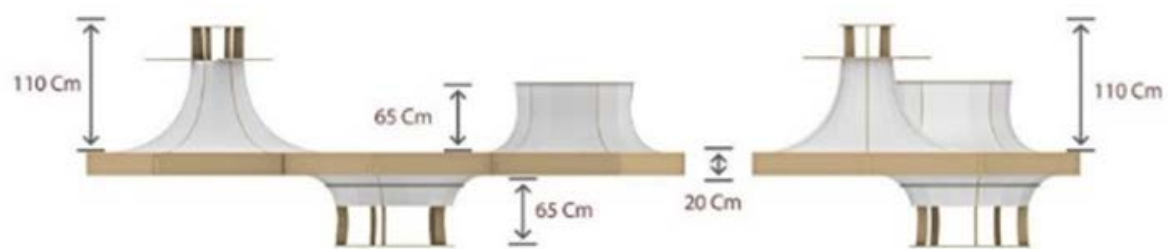

Front View $\quad$ Side View

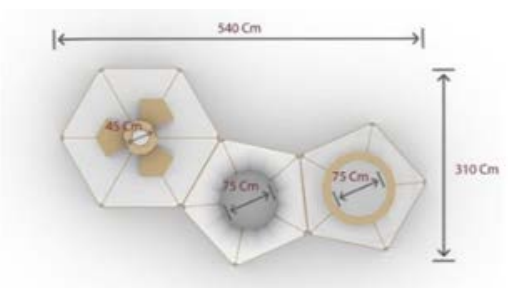

The structure of the system is composed of $2 \mathrm{~mm}$ thick wood panels, cut in slice profile shapes on CNC. These slice profiles are connected with a horizontal circular hoop on its end and a vertical pentagon/hexagon base, forming a sound backbone structure. Wooden platforms integrated into the crested structures attract cormorant birds and provide space for nesting.

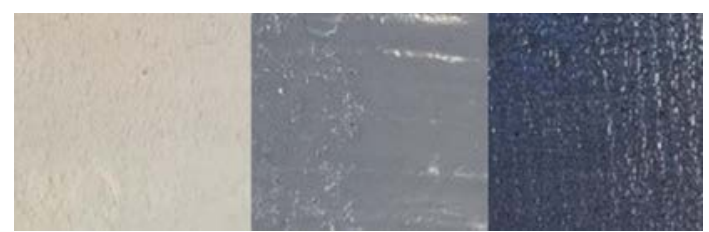



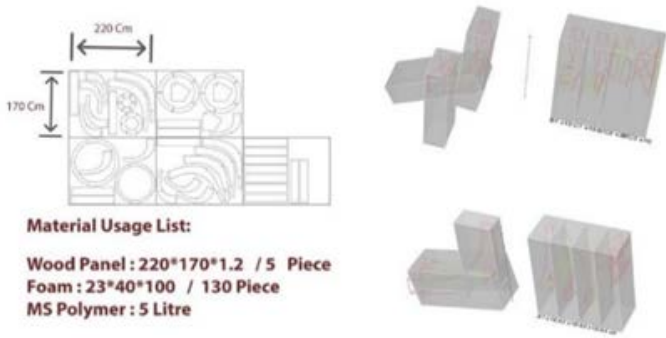

The body of each unit is composed of slices and filled with Styrofoam material, for its lightweight and buoyant properties as well as workability with wire-cutter and robot arm. In order to increase durability and waterproof quality of the modules, Isonem MS Polymer coating is proposed for the foam surfaces, particularly for its performance in a variety of real-life tests, performance with Styrofoam and its glossy surface. On the other hand, this coating is not considered to be suitable for ecological conditions hence not in conformity with the general design approach of the project. However, this criterion is ignored for the prototype design only, for economic and time-based considerations.

For the real prototype, 130 grains of styrofoam $23-40-100 \mathrm{~cm}$ in size, 220-170-1.2 cm in size wooden plate, 5 litres of Isonem MS Polymer, paste and silicone were used. In robotic cutting, the faulty parts were covered with mastic and cold silicone.

\section{CONCLUSIONS AND RECOMMENDATIONS}

Haliç first harbour, once recreation area and later the industrial quarter of İstanbul, had also established its ecosystem, which has been reduced mostly to Bahariye Islands and limited natural areas on the banks, as a result of dense urbanization with the 21st century, in parallel with the decrease of public utilization of the shores. An alternative way of generating public spaces again lies on contributing to the ecological life cycles of living organisms in Haliç habitat, hence increase the ecological quality and diversity of the natural areas. Through this way, both sides can be connected ecologically and quality of the public experience will be developed indispensable of the location of the public space.

Additionally, the utilization of computational design tools and contemporary fabrication technology usually recalls for human use. However, it must be possible to utilize the same tools to contribute directly to non-human living organisms and indirectly to the public life of human beings. The project discussed in the text prefers, rather than supporting ecology in extreme conditions or marketing the concept of ecology, to support and develop the natural life and create awareness for the problems of diminishing habitat in Haliç.
Figure 21. Material Usage Reducing (Design by the Designers). 
Figure 22. $1 / 5$ Scale \& $1 / 1$ Scale (Photograph by the Authors)

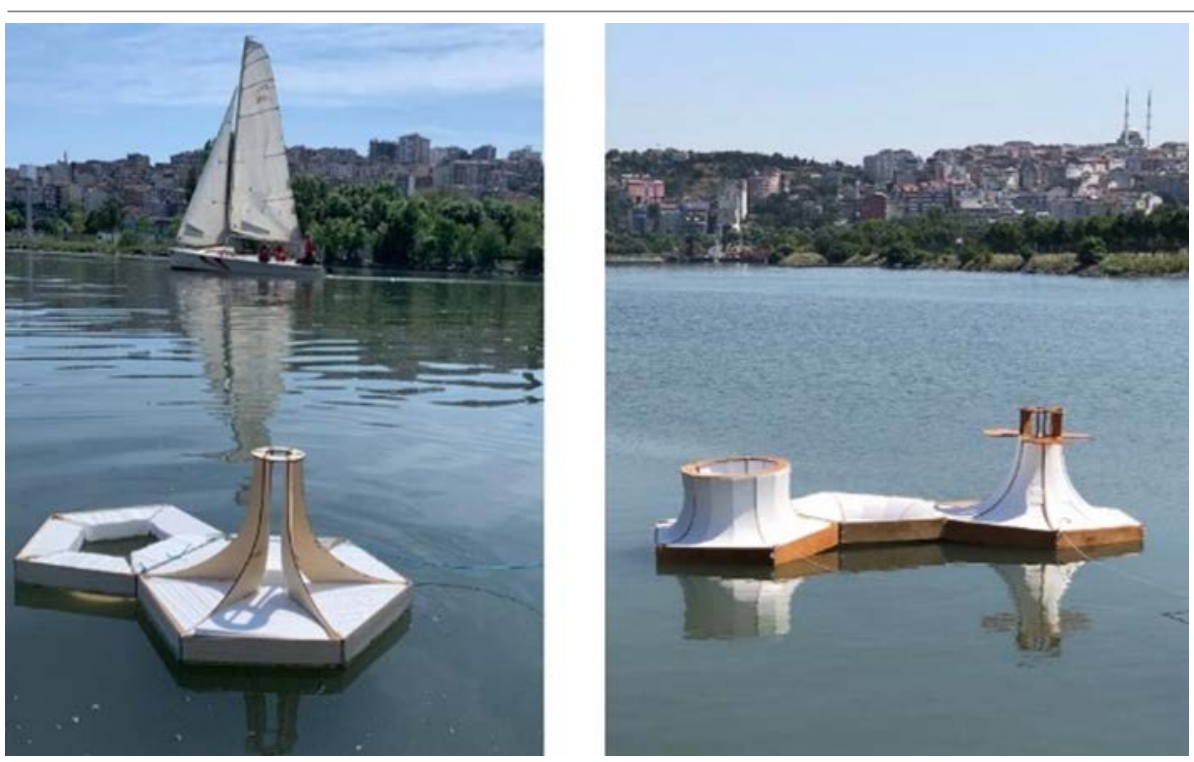

This project proposes an experimental floating structure, designed to research the parameters and fabrication process. Therefore, the determination of production style and design language along with technological constraints are exemplary in order to reach a mature level in both design and use of information tools in the following years.

This study concentrates on the life cycles of cormorant species which is in danger of extinction. The research needs to be elaborated for plant and underwater life and holds the potential for adaptation for a variety of parameters based on other species as well as cormorant.

The design is modular and reproducible for a variety of parameters. Furthermore, thanks to its modular structure, it is possible to adopt the floating islands for other functions and even human use as well, so that it may further contribute for the public spaces in the context of raising awareness and attracting attention.

\section{ACKNOWLEDGEMENTS/NOTES}

Initially, we need to acknowledge the studio instructors Fulya Özsel Akipek and Abdurrahman Tuğrul Yazar, who contributed to each and every phase of the process as much as the authors of this text, if not more. In parallel, Shirin Housseinzadah, Behzad Jam, Mihrimah Yilmaz and Kübra Halıcı has to be primarily referred as studio participants and designers of the ecological island project.

Authors also wish to thank studio participants Deniz Karabekiroğlu, Kübra Koyuncu and Oğulcan Üneşi who contributed to the research phase. Furthermore, workshop instructor Tania Feldzer, lecturer Stefano Pugliese and simulation software developer İlker Karadağ are acknowledged for their significant contributions. We would also thank to Bilgi University fab-lab technician Rahman for fabrication process.

Finally, we would like to Prof. Dr. Zuhal Ulusoy, Dean of the Faculty of Architecture and Prof. Dr. Şebnem Yalınay Çinici Head of Department of Architecture for their academic and moral support. 


\section{FINANCIAL DISCLOSURE}

The authors declared that this study has received no financial support. However, Istanbul Bilgi University contributed financially to the production of the structure during the design process.

\section{ETHICS COMMITTEE APPROVAL}

Ethics committee approval was not required for this article.

\section{LEGAL PUBLIC/PRIVATE PERMISSIONS}

In this research, the necessary permissions were obtained from the relevant participants (individuals, institutions, and organizations) during the in-depth interviews.

\section{REFERENCES}

Adey, W. H. \& Loveland, K. (2007). Dynamic Aquaria: Building and restoring living ecosystems. Londra, UK: Academic.

Aksoy, A. \& Açıkbaș, F. \& Akman, A. (2007). Silahtarağa Elektrik Santrali'nin Hikayesi 1910-2004. İstanbul Bilgi Üniversitesi.

Akyıldız, A. (2007). Haliç'te Seyrüsefer Haliç Vapurları Şirketi. Türkiye İş Bankası Kültür Yayınları.

Berke, J. (2018). A New 'Floating Park' Made Out of Recycled Plastic Waste Has Popped Up In The Netherlands. Business Insider.

Boyla, K. A., Arslan, M., editors (2008). İstanbul'un Kuşları: 2000-2007, İstanbul, Turkey. İstanbul Kuş Gözlem Topluluğu. (in Turkish).

Boyla, K. A. (2019). Türkiye Üreyen Kuş Atlası-WWF Rapor. İstanbul, editor: Per, E.\& Yavuz, K. E., Türkiye Doğal Hayatı Koruma Vakfı.

Coccon, F., Borella, S., Simeoni, N., \& Malavasi, S. (2018). Floating rafts as breeding habitats for the Common tern, Sterna hirundo, Colonization patterns, abundance and reproductive success in Venice Lagoon. Rivista Italiana Di Ornitologia, 88(1), 23-32.

Çelik, Z. (1998). 19. Yüzyılda Osmanlı Başkenti; Değișen İstanbul. Türkiye Ekonomik ve Toplumsal Tarih Vakfi-Numune Matbaacılık.

De Jong, T. M., \& Drake, B. G. (1981). Seasonal patterns of plant and soil water potential on an irregularly-flooded tidal marsh. Aquatic Botany, Volume 11, 1-9.

Evren, B. (2000). İstanbul'un Deniz Hamamları ve Plajları. Seçkin İstanbul Kitaplığı. İnkılap Yayınevi, İstanbul.

Güngör, N. (1996). Seyyahların Kaleminden Şehr-i Şirin İstanbul. İstanbul: Milliyet Yayınları.

Koçu, R. E. (1966). Darphane, İstanbul Ansiklopedisi. 8. Cilt, Koçu Yayınları. İstanbul.

Köksal, T. G. \& Ahunbay, Z. (2010). İstanbul'daki Endüstri Mirası İçin Koruma ve Yeniden Kullanım Önerileri. İtüdergisi/a, 5(2). 
Design Research and Prototype Fabrication of a 'Floating Public Space' for Birds

Masters, D. G., \& Norman, H. C. (2016). Genetic and Environmental Management of Halophytes for Improved Livestock Production. In Halophytes for Food Security in Dry Lands, Academic Press, 243-257.

Ravenscroft, T. (2019). SO? Builds prototype floating house for postearthquake Istanbul. Dezeen. access address: https://www.dezeen.com/2019/01/03/so-prototype-floating-houseearthquake-istanbul/

Riise, J., Adeyemi, K. (2015). Case study: Makoko floating school. Current Opinion in Environmental Sustainability,Volume 13, 58-60, April.

Tutel, E. (2000). Haliç: dünden bugüne yedi tepenin koynunda uyuyan büyülü cennet. Dünya Yayıncıllk.

Yılmaz, G. I. (2008). Haliç Kıyı Şeridinde Sanayileşme ile Ortaya Çıkan Kentsel Dönüşüm, Rölöve Restorasyon Doktora Tezi, Yıldız Teknik Üniversitesi Fen Bilimleri Enstitüsü, İstanbul.

URL - 1 TRAKUS Türkiye'nin Anonim Kuşları. Gray Heron Habitats. https://www.trakus.org/kods_bird/uye/?fsx=2fsdl17@d\&tur=Gri\%20b al\%FDk\%E7\%FDl

URL - 2 Sutopya. Fox Tail Plant/ Ceratophyllum Demersum. https://sutopya.com/tag/tilki-kuyrugu/

URL - 3 İSKİ Report. (2019, September 13). Water Quality Report 2019. Istanbul Water and Sewerage Administration. https://www.iski.gov.tr/web/assets/SayfalarDocs/sukalite/WATERQU ALITY_MAY2019.pdf.pdf

\section{Resume}

Kutay Karabağ currently works at the Dept. of Architecture, Istanbul Bilgi University. Kutay does research in Architectural Conservation and Restoration, Adaptive Reuse, Industrial Heritage, History and Theory of Computational Design. His most recent publication is 'Bir Endüstri Mirası Olarak Antalya Dokuma Fabrikası'.

Zeynep SSahbaz graduated from Istanbul Bilgi University, Dept. of Architecture in 2018. During this period, participated in various contributions at the intersection of architecture and sociology. Currently she is a graduate student in Dept. of Architecture History, Theory and Criticism. She is interested in public design and issues of city-power. 